\title{
Article \\ Polyphasic Characterization of Microbiota of "Mastredda", a Traditional Wooden Tool Used during the Production of PDO Provola dei Nebrodi Cheese
}

\author{
Gabriele Busetta ${ }^{1}$, Giuliana Garofalo ${ }^{1}$, Guido Mangione ${ }^{2}$, Luigi Botta ${ }^{3}{ }^{-}$, Elena Franciosi ${ }^{4}$, \\ Rosalia Di Gerlando ${ }^{1}$, Massimo Todaro ${ }^{1}{ }^{1}$, Giuseppe Licitra ${ }^{2}$, Maria Luisa Scatassa ${ }^{5}$, \\ Raimondo Gaglio ${ }^{1, *(D)}$ and Luca Settanni ${ }^{1}$ (D)
}

Citation: Busetta, G.; Garofalo, G.; Mangione, G.; Botta, L.; Franciosi, E.; Di Gerlando, R.; Todaro, M.; Licitra, G.; Scatassa, M.L.; Gaglio, R.; et al. Polyphasic Characterization of Microbiota of "Mastredda", a Traditional Wooden Tool Used during the Production of PDO Provola dei Nebrodi Cheese. Appl. Sci. 2021, 11, 8647. https://doi.org/10.3390/ app11188647

Academic Editor: Athina S. Tzora

Received: 30 July 2021

Accepted: 12 September 2021

Published: 17 September 2021

Publisher's Note: MDPI stays neutral with regard to jurisdictional claims in published maps and institutional affiliations.

Copyright: (c) 2021 by the authors. Licensee MDPI, Basel, Switzerland. This article is an open access article distributed under the terms and conditions of the Creative Commons Attribution (CC BY) license (https:// creativecommons.org/licenses/by/ $4.0 /)$.
1 Dipartimento Scienze Agrarie, Alimentari e Forestali, Ed. 5, Università degli Studi di Palermo, Viale delle Scienze, 90128 Palermo, Italy; gabriele.busetta@unipa.it (G.B.); giuliana.garofalo01@unipa.it (G.G.); rosalia.digerlando@unipa.it (R.D.G.); massimo.todaro@unipa.it (M.T.); luca.settanni@unipa.it (L.S.)

2 Dipartimento di Agricoltura, Alimentazione e Ambiente (Di3A), Università degli Studi di Catania, Via Valdisavoia 5, 95123 Catania, Italy; guidomangione@gmail.com (G.M.); glicitra@unict.it (G.L.)

3 Dipartimento di Ingegneria, UdR INSTM di Palermo, Università degli Studi di Palermo, Viale delle Scienze, 90128 Palermo, Italy; luigi.botta@unipa.it

4 Research and Innovation Centre, Fondazione Edmund Mach (FEM), Via E. Mach 1, 38098 San Michele all'Adige, Italy; elena.franciosi@fmach.it

5 Istituto Zooprofilattico Sperimentale della Sicilia Adelmo Mirri, Via Gino Marinuzzi 3, 90129 Palermo, Italy; luisa.scatassa@izssicilia.it

* Correspondence: raimondo.gaglio@unipa.it

Abstract: The biofilms of the wooden tables used for the acidification of the curd were investigated for PDO Provola dei Nebrodi cheese, a traditional stretched cheese made in eastern Sicily (southern Italy) from raw cows' milk. To this purpose the wooden tables of four dairy facilities were analysed for their microbiota by scanning electron microscopy (SEM) analysis and a combined culture-independent and -dependent microbiological approach. SEM inspection showed an almost continuous biofilm formation. MiSeq Illumina analysis identified 8 phyla, 16 classes, 25 orders, 47 families and 50 genera. Corynebacterium, Bifidobacterium and lactic acid bacteria (LAB) were detected in all samples. In particular, the LAB genera detected on all wooden tables were Lactobacillus, Streptococcus and Lactococcus. LAB dominated the surfaces of all wooden tables with levels higher than 7.0 Log CFU $/ \mathrm{cm}^{2}$. In particular, the LAB found at the highest levels were mesophilic cocci. Coagulase positive staphylococci, Salmonella spp., Listeria monocytogenes and Shiga-toxigenic Escherichia coli were never detected. Twenty-seven dominating LAB strains were identified within the genera Enterococcus, Lactobacillus, Lacticaseibacillus, Lactiplantibacillus, Levilactobacillus, Lactococcus, Leuconostoc, Pediococcus and Streptococcus. This work showed that the wooden table used during the production of PDO Provola dei Nebrodi cheese is a safe system and a microbiologically active tool.

Keywords: dairy wooden tool; lactic acid bacteria; Miseq Illumina; scanning electron microscopy; traditional cheese

\section{Introduction}

Provola dei Nebrodi is a stretched cheese produced in the Nebrodi Mountains area located in eastern Sicily (Southern Italy). This cheese is made from raw cows' milk without the addition of starter cultures [1] and, in 2020, it gained the protected denomination of origin (PDO) recognition by the European Union [2]. PDO Provola dei Nebrodi cheese has a typical pear-shape with a smooth, uniform and pale yellow crust. Five categories of these cheeses can be produced within PDO protocol of production: fresh (up to 1 month), semi-hard (ripened for 3-4 months), hard (ripened for 4-5 months), sfoglia (flaky; ripened more than 5 months) and with limone verde (green lemon; ripened more than 3 months). The entire production process of PDO Provola dei Nebrodi cheese is performed with wooden 
equipment [3], whose use is allowed in Europe by the commission regulation (EC) no. 2074/2005, which allows derogation from regulation EC no. 852/2004 for foods with traditional characteristics [4].

Wood is a traditional and natural material with a porous structure [5] able to absorb and retain microbial cells within a self-produced matrix of extracellular polymeric substance (EPS) known as "biofilms" [6]. In light of the alert issued from the US Food and Drug Administration on the potential presence of pathogenic bacteria about Italian and French cheeses ripened on wooden shelves [7], different research groups have focused their efforts to the microbial characterization of wooden equipment used in traditional dairy productions such as wooden vats [5,8-12] and wooden shelves [13-16]. Galinari et al. [15] also evaluated the wooden tables and forms used for moulding the Brazilian Minas cheese. All these studies detected the desired dairy lactic acid bacteria (LAB) on the wooden surfaces of all tools and equipment and reported the absence of the typical dairy pathogenic bacteria Listeria monocytogenes and Salmonella spp.

PDO Provola dei Nebrodi cheese, like all stretched cheeses, is made through a 2-step production: the first step consists of curdling and acidification, while the second step is aimed to stretch the acidified curd into the final cheese shape [17]. The acidification of the curd is performed by LAB. Since starter cultures are not deliberately added during production, the acidification process relies on the presence of LAB in the raw milk, on the surfaces of the wooden equipment and even in the animal rennet $[11,18,19]$. These LAB convert milk lactose into lactic acid very rapidly and, for this reason, the species of this group are classified as starter LAB (SLAB). The same sources can also transfer to the curd non starter LAB (NSLAB) which are mainly involved in the ripening process and influence several biochemical events necessary to provide the final cheeses with the typical aromatic profile [20].

The acidification process is particularly important for stretched cheeses because a $\mathrm{pH}$ drop in the range 5.2-5.4 is necessary for stretching [21,22], since dicalcium paracaseinate is converted into monocalcium paracaseinate determining the formation of fibres that can be reorganized to give shape and sheen to the cheese [23]. A pH value $>5.4$ does not allow stretching of the curd, while at $\mathrm{pH}$ below 5.2 the acidified curd is too tough due to the excessive fat loss [24]. After draining, the curd for PDO Provola dei Nebrodi cheese production is traditionally left to acidify at room temperature for about $24 \mathrm{~h}$ on a wooden open-topped table, namely "mastredda" [3] (Figure 1).

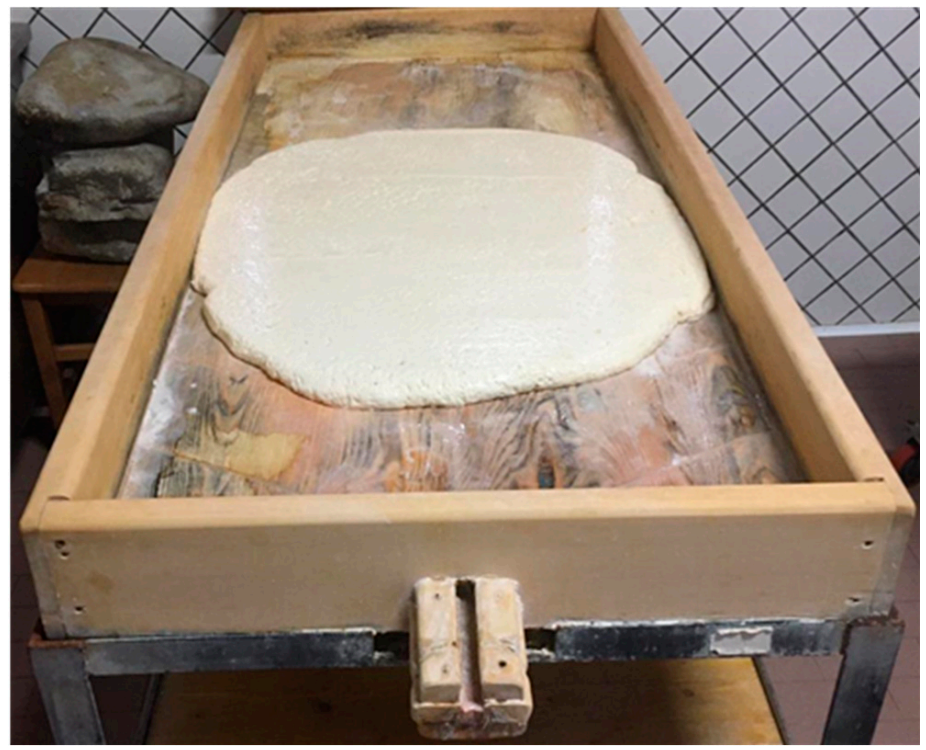

Figure 1. "Mastredda", a wooden table used for curd acidification during PDO Provola dei Nebrodi cheese production. 
So far, no study on the microbiological characterization of "mastredda" is available in the literature.

The purpose of the present research was to fill the gap in knowledge on the microbial biofilms of an important wooden tool used for traditional dairy productions. In particular, wooden tables of different dairy facilities producing PDO Provola dei Nebrodi cheese were investigated for their microbial biofilms through several approaches: scanning electron microscopy (SEM) inspection; culture-independent strategy applied to the bacterial community; plate counts of the main dairy-involved microbial groups; and isolation, characterization and identification of LAB.

\section{Materials and Methods}

\subsection{Collection of Wooden Table Biofilms}

The wooden tables used for curd acidification during PDO Provola dei Nebrodi cheese production were investigated from four dairy facilities of eastern Sicily (Italy) all located within Catania province (Table 1).

Table 1. Characteristics of the wooden tables used for curd acidification of PDO Provola dei Nebrodi cheese production.

\begin{tabular}{cccc}
\hline Wooden Table & $\begin{array}{c}\text { City of Dairy Factory } \\
\text { (Province) }\end{array}$ & Age of Table (Years) & ${\text { Type of Wood }{ }^{\mathbf{2}}}^{\text {Ayper fir }}$ \\
\hline WTA & Randazzo (CT) & 5 & silver fir \\
WTB & Maniace (CT) & 2 & silver fir \\
WTC & Randazzo (CT) & 8 & douglas fir \\
WTD & Randazzo (CT) & 10 & chestnut \\
\hline
\end{tabular}

${ }^{1}$ Province codes: CT, Catania. ${ }^{2}$ Tree species: silver fir, Abies alba L.; chestnut, Castanea sativa Miller; douglas fir, Pseudotsuga menziesii (Mirb.) Franco. Abbreviation: WT, wooden table; A-D, dairy factory A-dairy factory D.

Each wooden table surface $\left(100 \mathrm{~cm}^{2}\right)$ was delimited using a sterile paper square (Area Space 100, VWR International PBI s.r.l., Milan, Italy) to perform the biofilm collection by a non-destructive brushing method. To this purpose, the method described by Didienne et al. [9] was applied. Briefly, a sterile toothbrush was rubbed onto the wooden surface and a sterile cotton gauze was pressed onto the brushed area. Subsequently, the gauze was transferred into a sterile Durham bottle containing $100 \mathrm{~mL}$ of Ringer's solution (SigmaAldrich, Milan, Italy) where the toothbrush was previously washed. Wooden table surface collection was performed in two technical repeats (two adjacent areas) and repeated after one month for a total of four collections in two independent sampling days. The wooden tables are cleaned from time to time by brushing with the hot $\left(70-80{ }^{\circ} \mathrm{C}\right)$ deproteinized whey that results from Ricotta cheese production [25]. All samples were transported with a portable fridge to the Agricultural Microbiology laboratory (Department of Agricultural, Food and Forestry Science, University of Palermo, Palermo, Italy).

\subsection{Scanning Electron Microscopy}

The presence of the biofilms on the surface of the wooden tables was also analysed by a destructive method to perform the scanning electron microscopic (SEM) investigation. Square wood splinters (approximately $10 \mathrm{~mm}$ by $10 \mathrm{~mm}$ by $2 \mathrm{~mm}$ ) were aseptically collected from each wooden table with a sterile stainless steel scalpel [26]. Wooden samples were analysed using the FEI ESEM Quanta 200 apparatus (FEI Company, Hillsboro, OR, USA) at the Department of Engineering of the University of Palermo (Italy). Before being mounted on the aluminium holder, the splinters were dehydrated [27] and dried [5]. A thin layer of gold (20 m $\AA 300 \mathrm{~s}$ ) (Edwards S150A sputter coater) under argon atmosphere for $90 \mathrm{~s}$ (Scancoat Six Ed-wards, Crawley, UK) was spattered on the wooden samples to avoid electrostatic charging under electron beam. 


\subsection{DNA Extraction, Miseq Library Preparation and Illumina Sequencing}

Cell suspensions $(10 \mathrm{~mL})$ of each wooden table biofilm were centrifuged at $3200 \times g$ for $15 \mathrm{~min}$ at $4{ }^{\circ} \mathrm{C}$ [28]. Cell pellets $(10 \mathrm{mg})$ were harvested and used to extract total genomic DNA using the QIAamp ${ }^{\circledR}$ DNA Investigator Kit (QIAGEN, Hilden, Germany) following the manufacturer's instructions. The DNA quality and concentrations were determined by NanoDrop ${ }^{\mathrm{TM}} 8000$ Microvolume UV-Vis spectrophotometer (ThermoFisher Scientific, Inc., Wilmington, DE, USA). Amplicon library preparation, quality and quantification of pooled libraries, and pair-end sequencing using the Illumina MiSeq system were carried out at the Sequencing Platform in Fondazione Edmund Mach (FEM, San Michele a/Adige, Italy). Briefly, total genomic DNA was amplified using primers specific to the bacterial $16 \mathrm{~S}$ rRNA gene $[29,30]$. Each sample was amplified by PCR using $25 \mu \mathrm{L}$ reaction with $1 \mu \mathrm{M}$ of each primer. PCR reactions were executed by GeneAmp PCR System 9700 (Thermo Fisher Scientific, Waltham, MA, USA). The amplification products were checked on $1.5 \%$ agarose gel and purified using the Agencourt AMPure XP system (Beckman Coulter, Brea, CA, USA), following the manufacturer's instructions. Afterward, a second PCR was used to apply dual indices and Illumina sequencing adapters Nextera XT Index Primer (Illumina, San Diego, CA, USA). The amplicon libraries were purified using Agencourt AMPure XP system (Beckman), and the quality control was performed on a Typestation 2200 platform (Agilent Technologies, Santa Clara, CA, USA). Finally, all barcoded libraries were pooled in an equimolar ratio and sequenced on an Illumina ${ }^{\circledR}$ MiSeq (PE300) platform (MiSeq Control Software 2.5.0.5 and Real-Time Analysis software 1.18.54.0).

\subsection{Illumina Data Analysis and Sequences Identification by QIIME2}

Raw paired-end FASTQ files were demultiplexed using idemp (https:/ / github.com/ yhwu/idemp/blob/master/idemp.cpp, accessed on 29 July 2021) and imported into Quantitative Insights into Microbial Ecology (Qiime2, version 2020.8). Sequences were denoised and merged using DADA2 [31]. DADA2 was run as described in https://benjjneb. github.io/dada2/tutorial.html (accessed on 29 July 2021) using the default parameters. In order to improve the overall quality of the sequences, the reads were quality filtered and trimmed using the Filter and Trim functions implemented in DADA2. Chimeric sequences had been identified and removed via the consensus method in DADA2. The taxonomic assignment and compositional analyses were carried on by using plugins feature-classifier (https:/ / github.com/ qiime2/ q2-feature-classifier, accessed on 29 July 2021)) and performed using a pre-trained naïve Bayesian classifier method based on the Greengenes 13_8 99\% Operational Taxonomic Units (OTUs) database which had been previously trimmed to the $\mathrm{V} 4$ region of $16 \mathrm{~S} \mathrm{rDNA}$, bound by the $341 \mathrm{~F} / 805 \mathrm{R}$ primer.

The FASTQ files generated by MiSeq Illumina sequencing were deposited in the NCBI Sequence Read Archive (SRA) and are available under Ac. Number PRJNA750672 (https:/ / www.ncbi.nlm.nih.gov/bioproject/750672, accessed on 29 July 2021).

\subsection{Classical Microbiological Analyses}

Biofilm cell suspensions ( $1 \mathrm{~mL}$ ) were also serially diluted (1:10) in Ringer's solution (Sigma-Aldrich, Milan, Italy). The consecutive dilutions were homogenized by vortexing the test tubes and plated on agar media for the following microbial groups: total mesophilic aerobic microorganisms (TMM) by spread plating on Plate Count Agar (PCA), incubated at $30^{\circ} \mathrm{C}$ for $48 \mathrm{~h}$; mesophilic and thermophilic LAB cocci on M17 agar incubated anaerobically for $72 \mathrm{~h}$ at $30^{\circ} \mathrm{C}$ and $44^{\circ} \mathrm{C}$, respectively; mesophilic and thermophilic LAB rods on MRS agar adjusted to $\mathrm{pH} 5.4$ with $5 \mathrm{Mol}$ lactic acid, incubated anaerobically for $72 \mathrm{~h}$ at $30^{\circ} \mathrm{C}$ and $44^{\circ} \mathrm{C}$, respectively; enterococci on kanamycin esculin azide (KEA) agar, incubated aerobically for $24 \mathrm{~h}$ at $37^{\circ} \mathrm{C}$. Pseudomonas spp. on Pseudomonas Agar Base (PAB) supplemented with $10 \mathrm{mg} / \mathrm{mL}$ cetrimide-fusidic acid, incubated at $25^{\circ} \mathrm{C}$ for $72 \mathrm{~h}$; Enterobacteriaceae on Violet red bile glucose agar (VRBGA), incubated at $37^{\circ} \mathrm{C}$ for $24 \mathrm{~h}$. In addition, all samples were also analyzed for the presence of the main pathogenic microorganisms: coagulase-positive staphylococci (CPS) on Baird Parker (BP) supplemented with rabbit 
plasma fibrinogen (RPF); Listeria spp. and Listeria monocytogenes on Listeria selective agar base with SR0140E supplement; Salmonella spp. and E. coli on Hektoen Enteric agar (HEA). All pathogens were incubated at $37^{\circ} \mathrm{C}$ for $24 \mathrm{~h}$. All media and supplements were purchased from Oxoid Microbiology Products (Thermo-Scientific, Milan, Italy), except HEA provided by Microbiol Diagnostici (Uta, Italy). Plate counts were performed in duplicate.

\subsection{Isolation, Grouping, Genotypic Differentiation and Identification of LAB}

After growth on MRS and M17 agar media, the colonies of presumptive mesophilic and thermophilic LAB with different morphologies were picked up from the plate. In order to cover the entire variability of viable LAB, at least five colonies sharing the same appearance (shape, size, margin edge, elevation, colour and opacity of surface) were collected for all morphologies distinguished. All isolates were purified by several streaking steps onto the same agar media used for plate count and tested for Gram type by treatment with $3 \%(w / v) \mathrm{KOH}$ method [32], and for catalase test performed by the addition of $\mathrm{H}_{2} \mathrm{O}_{2}$ at $3 \%(v / v)$ to the colonies [33]. Pure cultures were first subjected to a grouping based on cell morphology and arrangement of the cells [34], and then analysed for their physiological and biochemical traits as described by Gaglio et al. [35]. LAB cocci were further analysed for their growth at $\mathrm{pH} 9.2$ and in the presence of $\mathrm{NaCl}(6.5 \mathrm{~g} / \mathrm{L})$ to discriminate enterococci from other dairy LAB cocci.

In order to restrict the number of presumptive LAB to be subjected to the genetic identification, all cultures were subjected to strain typing by random amplification of polymorphic DNA (RAPD)-PCR analysis. Genomic DNAs were extracted from overnight grown cultures using the DNA-SORB-B kit (Sacace Biotechnologies Srl, Como, Italy) according to the manufacturer's instructions. Crude cell extracts were amplified using singly the primers M13, AB111, and AB106 as reported by Gaglio et al. [36]. RAPD patterns were then analysed by GelCompar II software version 6.5 (Applied-Maths, Saint-Marten-Latem, Belgium) to obtain a dendrogram and evaluate the similarity among the LAB community. Genotypic identification of all different strains was performed by amplification and sequencing of the 16S rRNA gene [26]. The sequences obtained were compared to those available in the GenBank/EMBL/DDBJ (http:/ / www.ncbi.nlm.nih.gov, accessed on 12 July 2021) and EzTaxon-e (http:/ / eztaxon-e.ezbiocloud.net/, accessed on 12 July 2021) databases.

\subsection{Shiga-Toxigenic E. coli Detection}

In case of detection of E. coli colonies, they were analysed for their Shiga-toxigenic E. coli (STEC) genes. The multiplex PCR described by Osek [37] and designed on the genes for Shiga toxins 1 and 2 (st $x 1$ and st $x 2$ ) was applied on the E. coli isolates developed at the highest dilutions of the biofilms.

\subsection{Statistical Analyses}

Plate count data were subjected to one-way variance analysis (ANOVA) using XLStat software version 7.5.2 for Excel (Addinsoft, New York, NY, USA). The Tukey's test was applied for pairwise comparison between the different wooden table biofilms analysed. Statistical significance was attributed to $p$ values of $p<0.01$.

\section{Results and Discussion}

\subsection{Scanning Electron Microscopy of Wooden Table Biofilms}

The wooden splinters collected from the four tables, used for the curd acidification of PDO Provola dei Nebrodi, were evaluated for the presence of microbial biofilms by SEM, and the results of the analysis are shown in Figure 2. 


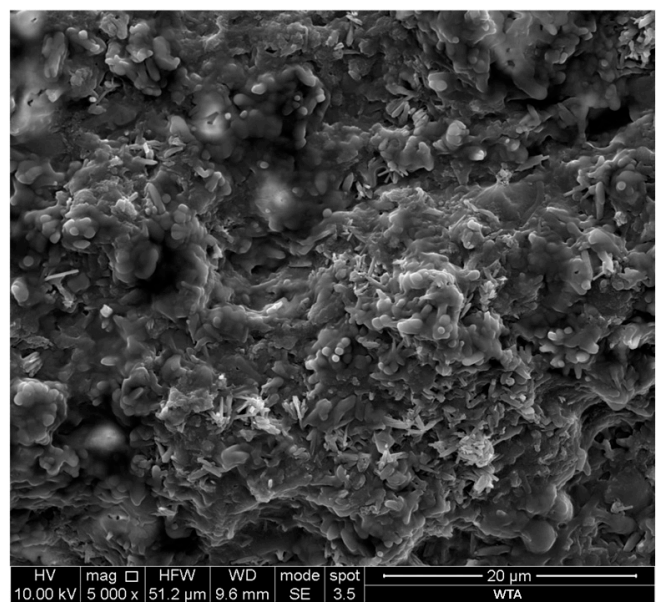

(a)

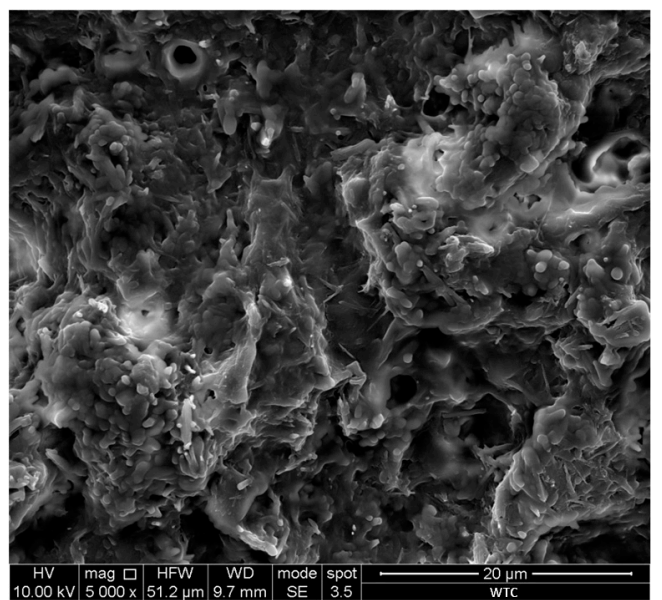

(c)

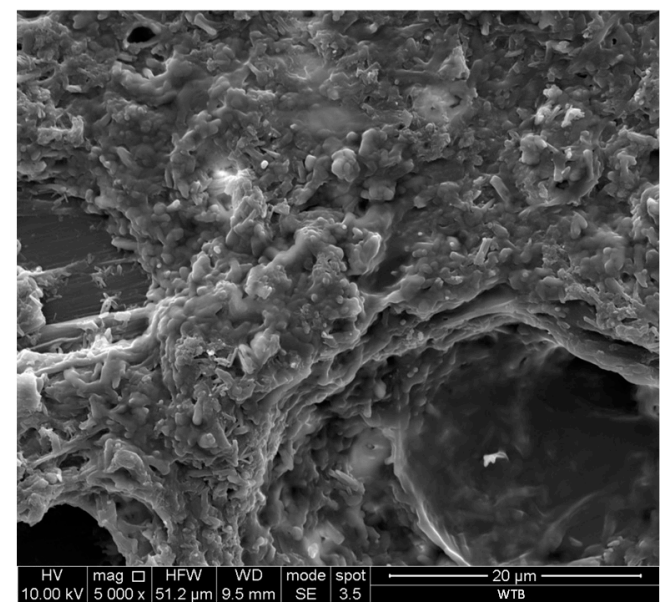

(b)

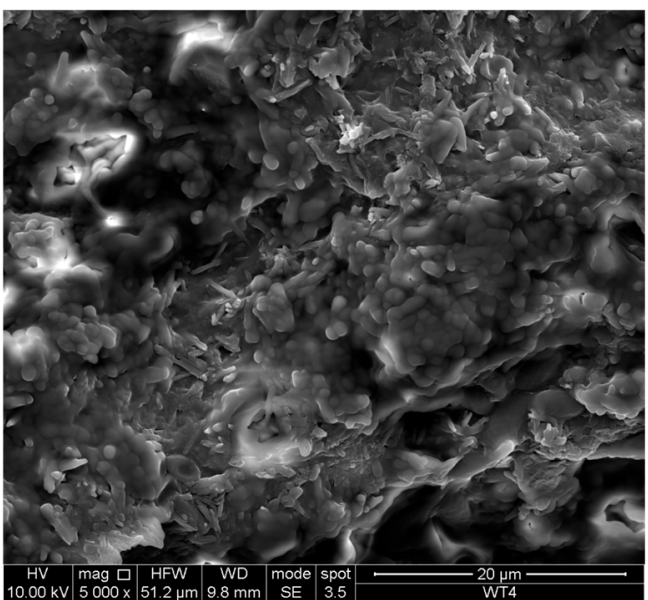

(d)

Figure 2. Scanning electron microscopy (SEM) observations of wooden splinters from wooden tables used during PDO Provola dei Nebrodi cheese production. Pictures of the wooden splinters from dairy factories A-D (a-d).

The images acquired by SEM clearly showed that the biofilm cover the wood surfaces of the tables entirely. As per the wooden vats used for milk curdling to produce other PDO and traditional cheeses $[5,12,26]$, the exopolysaccharide matrix typical of microbial biofilms is also clearly visible on the wooden tables used for the acidification of curds of PDO Provola dei Nebrodi cheese. However, the wood surface is rarely still recognizable (WTB). This inspection showed a consistent presence of coccus-shaped bacterial populations, while short rod bacteria were detected at lower densities.

\subsection{Taxonomic Distribution of Wooden Table Bacteria}

In recent years, the Illumina technology has been widely applied to reveal the entire bacterial composition of raw materials used in food production in order to also determine the dormant and/or viable but not cultivable bacterial community before processing [38-40]. In this study the DNA extracted from the biofilms collected in replicate collections from the four wooden table samples was successfully amplified in the bacterial V3-V4 16S rRNA gene region. A total of 320,396 paired-end sequences were obtained. The taxonomy classification allowed the identification of eight phyla, 16 classes, 25 orders, 47 families and 50 genera. The relative abundance (\%) of the operational taxonomy units (OTUs) identified from the biofilms is reported in Figure 3. 


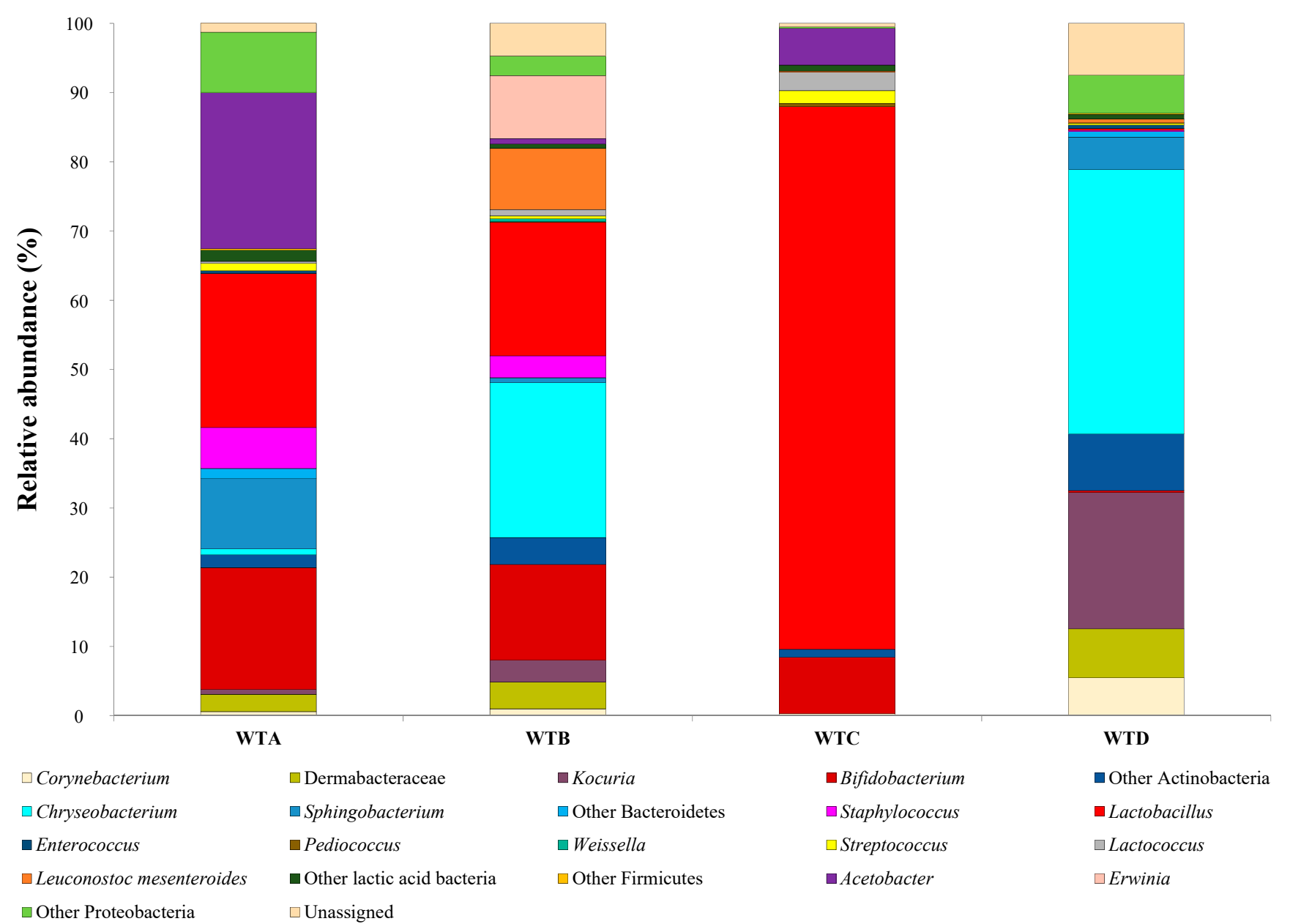

Figure 3. Relative abundances (\%) of bacteria identified by MiSeq Illumina in wooden table biofilms. Abbreviations: WT, wooden table; A-D, dairy factory A-dairy factory D.

The OTUs with an individual relative abundance $<0.1 \%$ were not considered since this is the threshold indicated for abundant communities [41].

All wooden tables were characterized for the presence of Corynebacterium, Bifidobacterium and LAB. In particular, the LAB genera detected on all four wooden tables were Lactobacillus, Streptococcus and Lactococcus. The abundance of these groups were greatly variable with Corynebacterium ranging from 0.29 to $5.80 \%$, Bifidobacterium from 0.29 to 17.69 , Streptococcus from 0.22 to $1.84 \%$, Lactococcus from 0.10 to $2.65 \%$ and, especially, Lactobacillus from barely 0.29 in WTD to $78.61 \%$ in WTC. The LAB group also included other genera found only in one sample like Weissella in WTB, or two samples like Enterococcus in WTA and WTD and Pediococcus in WTB and WTC or three samples as per Leuconostoc (with the species Leuconostoc mesenteroides) in WTB-WTD.

In dairy environments, corynebacteria represent part of the surface community of smear cheeses [42] and are also found on the wooden shelves used for cheese ripening $[13,16]$. Since they are not involved in curd acidification they colonize the wooden surfaces of the tables analysed as a result of an environmental contamination or they are transferred from the raw milk [43]. The presence of bifidobacteria on dairy equipment is not negative, since this bacteria are common human probiotics [44], but they do not have to interfere with the activities of LAB during cheese production [45]. It is not surprising that LAB constituted the dominant populations of wooden table biofilms. In fact, LAB form stable biofilms on the surfaces of the wooden vats used for cheese curdling [5,8-10,46-48] and a similar LAB development was even more expected on the surfaces of the tables used for the overnight curd acidification. 
Dermabacteraceae, Kocuria, Chryseobacterium, Sphingobacterium and Staphylococcus were not found in sample WTC. Among these, only Kocuria in WTD and Chryseobacterium in WTB were detected at very consistent levels (20.84 and $22.58 \%$, respectively). Dermabacteriaceae and Staphylococcaceae have been recently detected in raw milk used to process Italian hard cheeses [49]. In particular, Staphylococcus is part of the raw cow's milk bacterial community [50]. Kocuria is also found in raw cow's milk [51] and is even selected as adjunct culture to enhance flavour and sensory attributes of traditional cheeses [52]. Several Chryseobacterium species (C. joostei, C. oranimense and C. haifense) have been recently identified from raw milk [53-55]. These bacteria are generally psychrotolerant, lipolytic and proteolytic and, for these reasons, undesirable because they might cause alteration of cheeses. Regarding sphingobacteria, they are also psychrothropic and are involved in cheese lipolysis and proteolysis [56].

Acetobacter were identified in the samples WTA-WTC with a particularly high relative abundance (22.66\%) in WTA, while 9.18\% of WTB biofilm OTUs were allotted into Erwinia genus. Acetobacter are not involved in cheese production, but associated with fermented milks $[57,58]$. Thus, its presence on the wooden tables used for curd acidification is not particularly singular. Erwinia were detected only in one sample and this is quite obvious, since bacteria belonging to this genus are plant pathogens [59] and play no role in dairy production. Except other Actinobacteria, in the range 1.08-8.68\%, and other Proteobacteria, in the range $0.25-8.75 \%$, found in all four samples, several OTUs from three of the four wooden tables could not be assigned to a hierarchical level below phylum and were grouped as other Bacteroidetes and other Firmicutes.

\subsection{Levels of Viable Microorganisms}

Plate counts of the bacterial groups harbored onto the surfaces of the wooden tables object of investigation are reported in Table 2.

Table 2. Microbial load ${ }^{1}$ of the biofilms of the wooden tables used for curd acidification during PDO Provola dei Nebrodi cheese production.

\begin{tabular}{cccccc}
\hline \multirow{2}{*}{ Bacterial Counts } & \multicolumn{5}{c}{ Samples } \\
\cline { 2 - 5 } & WTA & WTB & WTC & WTD & $p$ Value \\
\hline TMM & $7.34 \pm 0.26$ & $7.43 \pm 0.25$ & $7.55 \pm 0.15$ & $7.21 \pm 0.21$ & 0.352 \\
Mesophilic rod LAB & $5.36 \pm 0.16$ & $5.82 \pm 0.21$ & $5.57 \pm 0.23$ & $5.55 \pm 0.21$ & 0.128 \\
Thermophilic rod LAB & $5.73 \pm 0.20$ & $5.35 \pm 0.17$ & $5.59 \pm 0.16$ & $5.39 \pm 0.13$ & 0.074 \\
Mesophilic coccus LAB & $7.39 \pm 0.13$ & $7.34 \pm 0.20$ & $7.25 \pm 0.18$ & $7.39 \pm 0.12$ & 0.690 \\
Thermophilic coccus LAB & $5.87 \pm 0.20$ & $5.79 \pm 0.21$ & $5.63 \pm 0.14$ & $5.39 \pm 0.13$ & 0.057 \\
Enterococci & $2.35 \pm 0.17^{\mathrm{C}}$ & $2.44 \pm 0.15^{\mathrm{BC}}$ & $2.78 \pm 0.15^{\mathrm{AB}}$ & $3.05 \pm 0.17^{\mathrm{AB}}$ & 0.0024 \\
Pseudomonas & $<1^{\mathrm{B}}$ & $2.97 \pm 0.12^{\mathrm{A}}$ & $<1^{\mathrm{B}}$ & $2.84 \pm 0.12^{\mathrm{A}}$ & 0.0001 \\
Enterobacteriaceae & $1.44 \pm 0.15^{\mathrm{D}}$ & $3.54 \pm 0.19^{\mathrm{A}}$ & $1.87 \pm 0.12^{\mathrm{C}}$ & $2.81 \pm 0.10^{\mathrm{B}}$ & 0.0001 \\
E. coli & $1.24 \pm 0.15^{\mathrm{C}}$ & $3.44 \pm 0.16^{\mathrm{A}}$ & $<1^{\mathrm{D}}$ & $2.39 \pm 0.13^{\mathrm{B}}$ & 0.0001 \\
\hline
\end{tabular}

${ }^{1}$ Units are $\log \mathrm{CFU} / \mathrm{cm}^{2}$ for area samples. Results indicate mean values \pm standard deviation (SD) of $\mathrm{n}=8$ plate counts (carried out in duplicates for two independent sampling). Abbreviation: WT, wooden table; A-D, dairy factory A-dairy factory D; TMM, total mesophilic microorganisms; LAB, lactic acid bacteria; E., Escherichia. On the row A, B, C, D: $p<0.01$.

According to Tukey's test, no statistically significant differences $(p>0.05)$ between the wooden table biofilms analysed were found for the levels of TMM and all LAB groups. TMM cell densities were higher than $7.0 \mathrm{Log} \mathrm{CFU} / \mathrm{cm}^{2}$ on all four wooden tables investigated. Lower levels of TMM were reported by Galinari et al. [15] on the wooden table used for the molding of artisanal Minas cheese made in the Serro and Serra da Canastra regions (4.29 and $4.58 \log \mathrm{CFU} / \mathrm{cm}^{2}$, respectively). In this case, the curd was in contact with the tables for a shorter time compared to the Provola dei Nebrodi curd. All wooden table surfaces displayed high levels of LAB (mesophilic and thermophilic rods and cocci). These findings were somewhat expected considering previous studies focused on wooden vat biofilm characterization $[5,8-11,60]$. The highest cell densities of LAB were registered 
for mesophilic LAB cocci. The levels of this LAB group were superimposable to those of TMM indicating that these bacteria dominated all wooden table biofilms. The dominance of cocci over rods was previously reported in wooden vats used for the production of PDO bovine $[9-11]$ and ovine $[11,12,61]$ cheeses. Enterococci were detected in all wooden table samples in the range 2.35-3.05 $\mathrm{Log} \mathrm{CFU} / \mathrm{cm}^{2}$. Similar levels of enterococci were found on the surfaces of the wooden vats used for making Caciocavallo Palermitano and PDO Vastedda della valle del Belìce cheeses [11] and on wooden shelves used in the ripening of a traditional French raw milk smear cheese [14]. However, high throughput analysis detected Enterococcus only in WTA and WTD biofilms, probably because Enterococcus were part of the unassigned OTUs of total bacterial community or they were below $0.1 \%$ of abundance or their DNAs were rendered inaccessible by nucleases. Regarding Pseudomonas spp., known agents of food spoilage [62], only the samples WTB and WTD were characterized by the presence of these bacteria with concentrations of about $3 \mathrm{Log} C F U / \mathrm{cm}^{2}$. Generally Pseudomonas spp. are absent or present at very low levels onto the surfaces of wooden equipment used in dairy facilities [10].

\subsection{Microbiological and Hygiene Criteria for Foodstuffs}

In light of the Commission Regulation (EC) No 2073/2005 on microbiological criteria for foodstuffs [63], Salmonella spp. and L. monocytogenes were analysed as food safety criteria, while E. coli and CPS as process hygiene criteria.

In general, the surfaces of the tables hosted low numbers of members of the Enterobacteriaceae family, except WTB that was also characterized for the highest cell density of E. coli (3.44 $\log \mathrm{CFU} / \mathrm{cm}^{2}$ ). This bacterium was also found on the surfaces of the tables WTA and WTD. Similar levels of E. coli have been previously observed on the surfaces of the wooden vats used for making PDO Salers cheese [9] and on those analysed by Lortal et al. [5] in eastern Sicily. Considering that, after Campylobacter and Salmonella, STEC was the third most frequent bacterial agent detected in food-borne outbreaks in the EU in 2019 [64], the presence of STEC genes was specifically investigated in this study, but they were not detected in any of E.coli isolated at the highest numbers from the wooden table biofilms. The specific search for CPS, L. monocytogenes and Salmonella spp. did not generate any colony (for this reason these results are not reported in Table 2), showing the hygienic suitability of the "mastredda" tool for the curd acidification of PDO Provola dei Nebrodi cheese. The absence of these bacteria is undoubtedly due to their inability to adhere or to survive in wooden table biofilms in the presence of acidic conditions generated by LAB $[5,10]$.

\subsection{Differentiation and Identification of Viable $L A B$}

After enumeration, 312 Gram positive and catalase negative colonies (putative LAB) were isolated from the agar media used for LAB counts. After microscopic inspection, the cultures were separated into 225 cocci and 89 rods. The combination of the morphologi$\mathrm{cal} /$ physiological/biochemical traits, separated all LAB into 11 groups (Table 3). 
Table 3. Phenotypic grouping of the LAB forming biofilms on the wooden table surfaces.

\begin{tabular}{|c|c|c|c|c|c|c|c|c|c|c|c|}
\hline \multirow[b]{2}{*}{ Characters } & \multicolumn{11}{|c|}{ Clusters } \\
\hline & $\begin{array}{c}1 \\
(n=10)\end{array}$ & $\begin{array}{c}2 \\
(n=51)\end{array}$ & $\begin{array}{c}3 \\
(n=9)\end{array}$ & $\begin{array}{c}4 \\
(n=19)\end{array}$ & $\begin{array}{c}5 \\
(n=85)\end{array}$ & $\begin{array}{c}6 \\
(n=36)\end{array}$ & $\begin{array}{c}7 \\
(n=13)\end{array}$ & $\begin{array}{c}8 \\
(n=29)\end{array}$ & $\begin{array}{c}9 \\
(n=14)\end{array}$ & $\begin{array}{c}10 \\
(n=11)\end{array}$ & $\begin{array}{c}11 \\
(n=37)\end{array}$ \\
\hline Morphology ${ }^{1}$ & $\mathrm{R}$ & $\mathrm{R}$ & $\mathrm{R}$ & $\mathrm{R}$ & $\mathrm{C}$ & $\mathrm{C}$ & $\mathrm{C}$ & $\mathrm{C}$ & $\mathrm{C}$ & $\mathrm{C}$ & $\mathrm{C}$ \\
\hline $\begin{array}{l}\text { Cell arrangement } \\
\text { Growth: }\end{array}$ & $\mathrm{sc}$ & sc & sc & $\mathrm{sc}$ & sc & $\mathrm{sc}$ & $\mathrm{sc}$ & sc & $\mathrm{t}$ & $\mathrm{t}$ & lc \\
\hline $15^{\circ} \mathrm{C}$ & - & + & + & + & + & + & + & + & + & + & - \\
\hline $45^{\circ} \mathrm{C}$ & + & + & + & - & - & + & - & + & + & + & + \\
\hline pH 9.2 & n.d. & n.d. & n.d. & n.d. & - & - & + & + & + & + & - \\
\hline $6.5 \% \mathrm{NaCl}$ & n.d. & n.d. & n.d. & n.d. & + & + & - & + & + & + & - \\
\hline $\begin{array}{l}\text { Resistance to } 60^{\circ} \mathrm{C} \\
\text { Hydrolysis of: }\end{array}$ & + & + & + & - & - & + & + & + & + & + & + \\
\hline arginine & - & - & + & - & - & + & + & + & - & + & + \\
\hline aesculin & + & + & + & + & - & + & + & + & - & + & - \\
\hline $\begin{array}{l}\text { Acid production from: } \\
\text { arabinose }\end{array}$ & - & + & + & + & + & + & - & + & + & + & + \\
\hline ribose & - & + & + & + & + & + & + & + & + & + & + \\
\hline xylose & - & + & + & + & + & + & - & + & + & + & + \\
\hline fructose & + & + & + & + & + & + & + & + & + & + & + \\
\hline galactose & + & + & + & + & + & + & + & + & + & + & + \\
\hline lactose & + & + & + & + & + & + & + & + & + & + & + \\
\hline sucrose & + & + & + & + & + & + & + & + & + & + & + \\
\hline glycerol & + & + & + & + & + & + & + & + & - & + & + \\
\hline $\mathrm{CO}_{2}$ from glucose & - & - & - & - & + & + & - & - & - & - & - \\
\hline
\end{tabular}

${ }^{1} \mathrm{R}$, rod; C, coccus. ${ }^{2} \mathrm{sc}$, short chain; t, tetrads; lc, long chain. Abbreviation: n.d., not determined.

The highest number of groups (seven) was observed for cocci which presented three main cell arrangements: short chains (four groups), tetrads (two groups), and long chains (one group). Among these, two groups (5-6) were able to generate $\mathrm{CO}_{2}$ from glucose, displaying an obligate hetero-fermentative metabolism. The community of rod isolates included four groups and all of them showed a homo-fermentative metabolism. About 50\% of the isolates representing each phenotypic group was analyzed by RAPD-PCR, a genotypic approach commonly applied, to perform the strain typing of the LAB associated with food products [35]. With this approach, 27 distinct RAPD profiles representing 27 strains were recognized (Figure 4), indicating the validity of this technique for differentiating LAB associated with the wooden equipment as previously reported by Cruciata et al. [12]. The sequencing of the $16 \mathrm{~S}$ rRNA gene confirmed that all 27 strains belonged to the LAB group and they were allotted into nine genera (Enterococcus, Lactobacillus, Lacticaseibacillus, Lactiplantibacillus, Levilactobacillus, Lactococcus, Leuconostoc, Pediococcus and Streptococcus). The 11 species identified were deposited to GenBank as follows: Enterococcus casseliflavus (Ac. No. MZ669935); Enterococcus gallinarum (Ac. No. MZ669936); Lactobacillus delbrueckii (Ac. No. MZ669937); Lactococcus lactis (Ac. No. MZ669938); Lacticaseibacillus rhamnosus (Ac. No. MZ669939-MZ669943); Lactiplantibacillus plantarum (Ac. No. MZ669944-MZ669945) and Levilactobacillus brevis (Ac. No. MZ669946); Leuconostoc mesenteroides (Ac. No. MZ669947MZ669953); Leuconostoc pseudomesenteroides (Ac. No. MZ669954-MZ669956); Pediococcus acidilactici (Ac. No. MZ669957-MZ669958); Steptococcus thermophilus (Ac. No. MZ669959MZ669961). All these species are generally associated to dairy environments such as raw milk [50], cheeses [35,46], animal rennets [19] and wooden vats [11], considering that $L c b$. rhamnosus, Lpb. plantarum and Lvb. brevis were formerly Lactobacillus rhamnosus, Lactobacillus plantarum and Lactobacillus brevis, respectively [65]. In particular, Lcb. rhamnosus are typically associated to the ripening of PDO Provola dei Nebrodi cheese and have been recently object of selection for non starter $\mathrm{LAB}$ addition due to their desirable technological and enzymatic activities [66]. Pediococci are also generally isolated from semi-ripened PDO Provola dei Nebrodi cheeses [67]. 


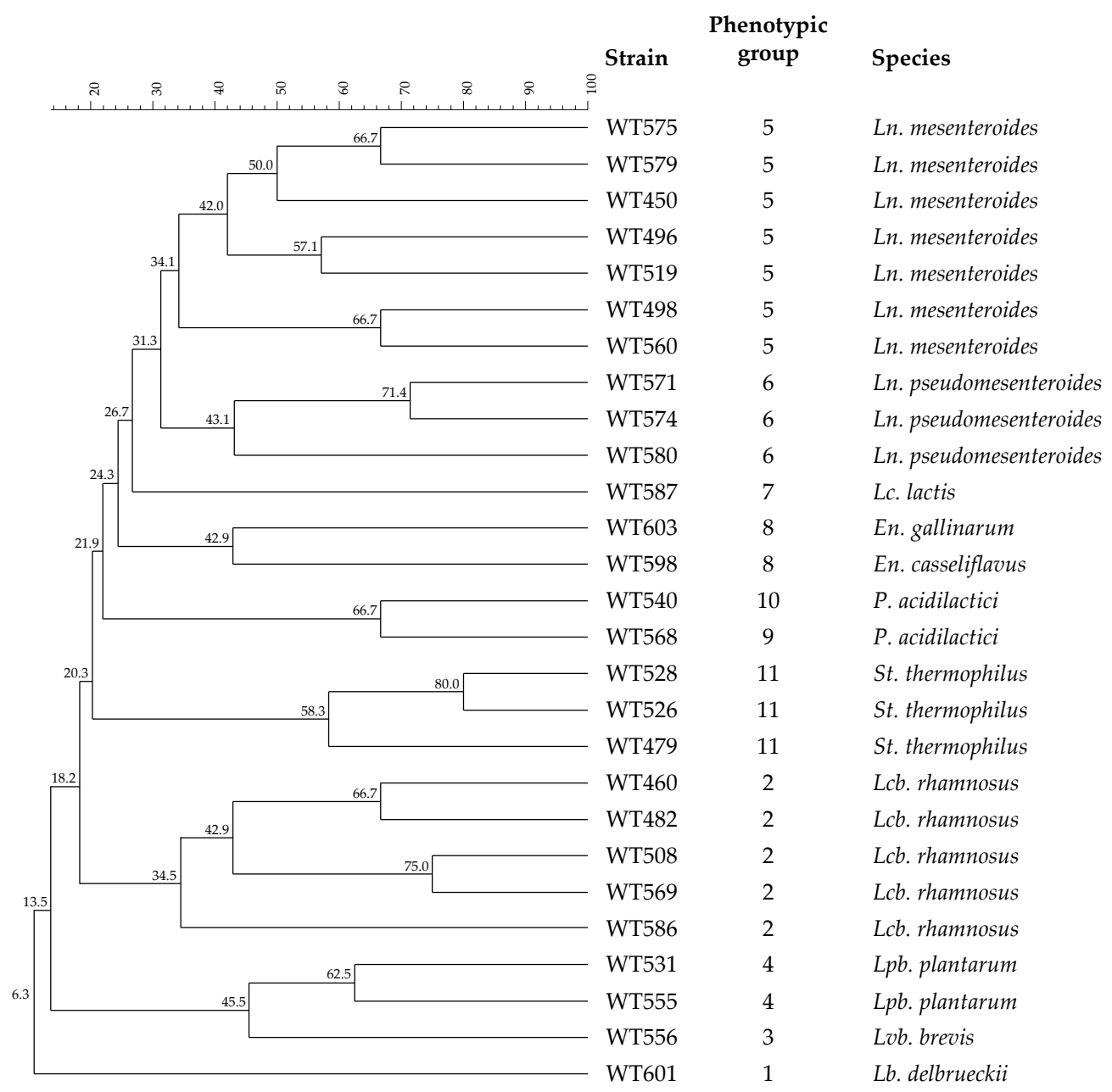

Figure 4. Dendogram obtained from combined RAPD-PCR patterns generated with three primers of the LAB strains identified. Abbreviations: En., Enterococcus; Lb., Lactobacillus; Lcb., Lacticaseibacillus; Lc., Lactococcus; Lpb., Lactiplantibacillus; Ln., Leuconostoc; Lvb., Levilactobacillus; P., Pediococcus; St., Streptococcus.

\subsection{Species Distribution}

The distribution of LAB species among the wooden tables used for the curd acidification of PDO Provola dei Nebrodi cheese is reported in Table 4.

Table 4. Distribution of LAB species among wooden tables.

\begin{tabular}{llll}
\hline LAB Species & \multicolumn{3}{c}{ Wooden Tables } \\
\cline { 2 - 4 } & WTA & WTB & WTC \\
\hline En. casseliflavus \\
En. gallinarum \\
Lb. delbrueckii \\
Lc. lactis \\
Lcb. rhamnosus \\
Lpb. plantarum \\
Lvb. brevis \\
Ln. mesenteroides \\
Ln. pseudomesenteroides \\
P. acidilactici \\
St. thermophilus
\end{tabular}


Ln. mesenteroides were the only LAB species found in all four wooden table surfaces. En. casseliflavus, En. gallinarum, Lb. delbruekii, Lc. lactis and Ln. pseudomesenteroides were found associated only to the WTD sample, as well as Lpb. plantarum, Lvb. brevis and P. acidilactici to the WTC sample. St. thermophilus was isolated only from the WTA and WTB samples. Additionally, in this case, the discrepancy between the culture-dependent and culture-independent survey might be imputable, as reported above, to the fact that some species were not detected by Illumina analysis because those species were part of the unassigned OTUs of total bacterial community or they were below $0.1 \%$ of abundance or their DNAs were rendered inaccessible by nucleases.

\section{Conclusions}

This work provided, for the first time, an in-depth microbiological characterization of the wooden tables, namely "mastredda", used for the acidification of the curd of PDO Provola dei Nebrodi cheese. The combined approach based on high throughput DNA analysis, enumeration, isolation and identification of LAB and evaluation of food safety and process hygiene criteria undoubtedly demonstrated the absence of risk factors associated to the wooden tables. The dominance of Lactobacillus, Streptococcus and Lactococcus proved the positive role of this traditional tool to transfer the typical LAB that favour the acidification process, which is of paramount importance for cheese productions carried out with raw milk without the addition of commercial starter cultures. On the whole, this study contributed to valorize a typical niche dairy product unrevealing the microbiota of the wooden tables in contact with cheese curd and provided further evidence on the suitability of wooden equipment in traditional cheese making.

Author Contributions: Conceptualization, G.L., R.G. and L.S.; methodology, R.G. and L.S.; software, E.F. and R.G.; validation, L.B., E.F., R.D.G., M.L.S. and R.G.; formal analysis, R.G. and L.S.; investigation, G.B., G.G., G.M., L.B., E.F. and R.D.G.; resources, M.T.; data curation, R.G.; writing-original draft preparation, R.G. and L.S.; writing-review and editing, R.G. and L.S.; project administration, M.T.; funding acquisition, M.T. All authors have read and agreed to the published version of the manuscript.

Funding: This work was supported by AGER 2 Project, grant No. 2017-1144.

Institutional Review Board Statement: Not applicable.

Informed Consent Statement: Not applicable.

Data Availability Statement: All data included in this study are available upon request by contacting the corresponding author.

Conflicts of Interest: The authors declare that they have no conflict of interest.

\section{References}

1. Ziino, M.; Condurso, C.; Romeo, V.; Giuffrida, D.; Verzera, A. Characterization of "Provola dei Nebrodi", a typical Sicilian cheese, by volatiles analysis using SPME-GC/MS. Int. Dairy J. 2005, 15, 585-593. [CrossRef]

2. Italian Ministerial Decree, 309/2020. Decreto Ministeriale 23 Settembre 2020, n.309. Iscrizione della Denominazione «Provola dei Nebrodi» DOP nel Registro Europeo delle Denominazioni di Origine Protette e delle Indicazioni Geografiche Protette, Gazzetta Ufficiale, Serie Generale, n. 243. pp. 32-37. Available online: https://www.gazzettaufficiale.it/eli/id/2020/10/01/20A05246/sg (accessed on 30 June 2021).

3. Licitra, G.; Caccamo, M.; Valence, F.; Lortal, S. Traditional wooden equipment used for cheesemaking and their effect on quality. In Global Cheesemaking Technology, 1st ed.; Papademas, P., Bintsis, T., Eds.; Wiley: Hoboken, NJ, USA, 2018 ; pp. $157-172$.

4. Commission Regulation (EC) No 2074/2005 of 5 December 2005 laying down implementing measures for certain products under regulation (EC) No 853/2004 of the European parliament and of the Council and for the organisation of official controls under regulation (EC) No 854/2004 of the European parliament and of the Council and regulation (EC) no 882/2004 of the European parliament and of the Council, derogating from regulation (EC) No 852/2004 of the European parliament and of the Council and amending regulations (EC) No 853/2004 and (EC) No 854/2004. Off. J. Eur. Union 2005, 338, 27-59. Available online: https:/ / eur-lex.europa.eu/legal-content/EN/ALL/?uri=celex\%3A32005R2074 (accessed on 30 June 2021). 
5. $\quad$ Lortal, S.; Di Blasi, A.; Madec, M.N.; Pediliggieri, C.; Tuminello, L.; Tangury, G.; Fauquant, J.; Lecuona, Y.; Campo, P.; Carpino, S.; et al. Tina wooden vat biofilm. A safe and highly efficient lactic acid bacteria delivering system in PDO Ragusano cheese making. Int. J. Food Microbiol. 2009, 132, 1-8. [CrossRef]

6. Azeredo, J.; Azevedo, N.F.; Briandet, R.; Cerca, N.; Coenye, T.; Costa, A.R.; Desvaux, M.; Di Bonaventura, G.; Hébraud, M.; Jaglic, Z.; et al. Critical review on biofilm methods. Crit. Rev. Microbiol. 2017, 43, 313-351. [CrossRef] [PubMed]

7. Cutini, F.; (Food: Divina (LN), the FDA Declares War on Our Chesees, AgenParl, Roma, Italy). Personal communication, 2014.

8. Licitra, G.; Ogier, J.C.; Parayre, S.; Pediliggieri, C.; Carnemolla, T.M.; Falentin, H.; Madec, M.N.; Carpino, S.; Lortal, S. Variability of the bacterial biofilms of the "tina" wood vat used in the Ragusano cheese-making process. Appl. Environ. Microbiol. 2007, 73, 6980-6987. [CrossRef] [PubMed]

9. Didienne, R.; Defargues, C.; Callon, C.; Meylheuc, T.; Hulin, S.; Montel, M.C. Characteristics of microbial biofilm on wooden vats ('gerles') in PDO Salers cheese. Int. J. Food Microbiol. 2012, 156, 91-101. [CrossRef] [PubMed]

10. Settanni, L.; Di Grigoli, A.; Tornambé, G.; Bellina, V.; Francesca, N.; Moschetti, G.; Bonanno, A. Persistence of wild Streptococcus thermophilus strains on wooden vat and during the manufacture of a Caciocavallo type cheese. Int. J. Food Microbiol. 2012, 155, 73-81. [CrossRef] [PubMed]

11. Scatassa, M.L.; Gaglio, R.; Macaluso, G.; Francesca, N.; Randazzo, W.; Cardamone, C.; Di Grigoli, A.; Moschetti, G.; Settanni, L. Transfer, composition and technological characterization of the lactic acid bacterial populations of the wooden vats used to produce traditional stretched cheeses. Food Microbiol. 2015, 52, 31-41. [CrossRef]

12. Cruciata, M.; Gaglio, R.; Scatassa, M.L.; Sala, G.; Cardamone, C.; Palmeri, M.; Moschetti, G.; La Mantia, T.; Settanni, L. Formation and characterization of early bacterial biofilms on different wood typologies applied in dairy production. Appl. Environ. Microbiol. 2018, 84, e02107-17. [CrossRef]

13. Mariani, C.; Briandet, R.; Chamba, J.F.; Notz, E.; Carnet-Pantiez, A.; Eyoug, R.N.; Oulahal, N. Biofilm ecology of wooden shelves used in ripening the French raw milk smear cheese Reblochon de Savoie. J. Dairy Sci. 2007, 90, 1653-1661. [CrossRef]

14. Mariani, C.; Oulahal, N.; Chamba, J.F.; Dubois-Brissonnet, F.; Notz, E.; Briandet, R. Inhibition of Listeria monocytogenes by resident biofilms present on wooden shelves used for cheese ripening. Food Control 2011, 22, 1357-1362. [CrossRef]

15. Galinari, É.; Nóbrega, J.E.D.; Andrade, N.J.D.; Ferreira, C.L.D.L.F. Microbiological aspects of the biofilm on wooden utensils used to make a Brazilian artisanal cheese. Braz. J. Microbiol. 2014, 45, 713-720. [CrossRef] [PubMed]

16. Guzzon, R.; Carafa, I.; Tuohy, K.; Cervantes, G.; Vernetti, L.; Barmaz, A.; Larcher, R.; Franciosi, E. Exploring the microbiota of the red-brown defect in smear-ripened cheese by 454-pyrosequencing and its prevention using different cleaning systems. Food Microbiol. 2017, 62, 160-168. [CrossRef] [PubMed]

17. Sciancalepore, V. Industrie Agrarie: Olearia, Enologica, Lattiero-Casearia, 1st ed.; Utet: Milano, Italy, 1998.

18. Franciosi, E.; Settanni, L.; Carlin, S.; Cavazza, A.; Poznanski, E. A factory-scale application of secondary adjunct cultures selected from lactic acid bacteria during "Puzzone di Moena" cheese ripening. J. Dairy Sci. 2008, 91, 2981-2991. [CrossRef] [PubMed]

19. Cruciata, M.; Sannino, C.; Ercolini, D.; Scatassa, M.L.; De Filippis, F.; Mancuso, I.; La Storia, A.; Moschetti, G.; Settanni, L. Animal rennets as sources of dairy lactic acid bacteria. Appl. Environ. Microbiol. 2014, 80, 2050-2061. [CrossRef]

20. Settanni, L.; Moschetti, G. Non-starter lactic acid bacteria used to improve cheese quality and provide health benefits. Food Microbiol. 2010, 27, 691-697. [CrossRef] [PubMed]

21. Niro, S. Innovazione di Processo e di Prodotto in Formaggi a Pasta Filata. Ph.D. Thesis, University of Molise, Campobasso, Italy, 2011.

22. Gaglio, R.; Scatassa, M.L.; Cruciata, M.; Miraglia, V.; Corona, O.; Di Gerlando, R.; Portolano, P.; Moschetti, G.; Settanni, L. In vivo application and dynamics of lactic acid bacteria for the four-season production of Vastedda-like cheese. Int. J. Food Microbiol. 2014, 177, 37-48. [CrossRef]

23. Jana, A.H.; Mandal, P.K. Manufacturing and quality of mozzarella cheese: A review study. Int. J. Dairy Sci. 2011, 6, 199-226. [CrossRef]

24. Kosikowski, F.V. Problems in the Italian soft cheese industy. J. Dairy Sci. 1958, 41, 455-458. [CrossRef]

25. Settanni, L.; Cruciata, M.; Guarcello, R.; Francesca, N.; Moschetti, G.; La Carrubba, V.; Gaglio, R. Valorisation of dairy wastes through kefir grain production. Waste Biomass Valoriz. 2020, 11, 3979-3985. [CrossRef]

26. Gaglio, R.; Cruciata, M.; Di Gerlando, R.; Scatassa, M.L.; Mancuso, I.; Sardina, M.T.; Moschetti, G.; Portolano, B.; Settanni, L. Microbial activation of wooden vats used for traditional cheese production and evolution of the neo-formed biofilms. Appl. Environ. Microbiol. 2016, 82, 585-595. [CrossRef] [PubMed]

27. Mallia, S.; Carpino, S.; Corralo, L.; Tuminello, L.; Gelsonimo, R.; Licitra, G. Effects of aroma profiles of Piacentinu and Ricotta cheese using different tool materials during cheese making. In Food Flavor and Chemistry: Explorations into the 21st Century, 1st ed.; Spanier, A.M., Shahidi, F., Parliment, T.H., Mussinan, C., Ho, C.T., Tratras Contis, E., Eds.; Royal Society of Chemistry: Cambridge, UK, 2005; pp. 23-34.

28. Gaglio, R.; Franciosi, E.; Todaro, A.; Guarcello, R.; Alfeo, V.; Randazzo, C.L.; Settanni, L.; Todaro, M. Addition of selected starter/non-starter lactic acid bacterial inoculums to stabilise PDO Pecorino Siciliano cheese production. Food Res. Int. 2020, 136, 109335. [CrossRef] [PubMed]

29. Baker, G.C.; Smith, J.J.; Cowan, D.A. Review and re-analysis of domain-specific 16 S primers. J. Microbiol. Methods. 2003, 55, 541-555. [CrossRef] 
30. Claesson, M.J.; Wang, Q.; O'Sullivan, O.; Greene-Diniz, R.; Cole, J.R.; Ross, R.P.; O'Toole, P.W. Comparison of two next-generation sequencing technologies for resolving highly complex microbiota composition using tandem variable 16S rRNA gene regions. Nucleic Acids Res. 2010, 38, e200. [CrossRef] [PubMed]

31. Callahan, B.J.; McMurdie, P.J.; Rosen, M.J.; Han, A.W.; Johnson, A.J.A.; Holmes, S.P. DADA2: High-resolution sample inference from Illumina amplicon data. Nat. Methods 2016, 13, 581-583. [CrossRef]

32. Gregersen, T. Rapid method for distinction of Gram-negative from Gram-positive bacteria. Eur. J. Appl. Microbiol. Biotechnol. 1978, 5, 123-127. [CrossRef]

33. Koneman, E.W.; Allen, S.D.; Janda, W.M.; Schreckenberger, P.C.; Winn, W.C. The nonfermentative gram-negative bacilli. In Color Atlas and Textbook of Diagnostic Microbiology, 7th ed.; Koneman, E.W., Allen, S.D., Janda, W.M., Schreckkenberger, P.C., Winn, W.C., Eds.; Lippincott: Philadelphia, PA, USA, 1997; pp. 253-320.

34. Barbaccia, P.; Busetta, G.; Matraxia, M.; Sutera, A.M.; Craparo, V.; Moschetti, G.; Francesca, N.; Settanni, L.; Gaglio, R. Monitoring Commercial Starter Culture Development in Presence of Red Grape Pomace Powder to Produce Polyphenol-Enriched Fresh Ovine Cheeses at Industrial Scale Level. Fermentation 2021, 7, 35. [CrossRef]

35. Gaglio, R.; Francesca, N.; Di Gerlando, R.; Cruciata, M.; Guarcello, R.; Portolano, B.; Moschetti, G.; Settanni, L. Identification, typing and investigation of the dairy characteristics of lactic acid bacteria isolated from "Vastedda della valle del Belìce" cheeses. Dairy Sci. Technol. 2014, 94, 157-180. [CrossRef]

36. Gaglio, R.; Francesca, N.; Di Gerlando, R.; Mahony, J.; De Martino, S.; Stucchi, C.; Moschetti, G.; Settanni, L. Enteric bacteria of food ice and their survival in alcoholic beverages and soft drinks. Food Microbiol. 2017, 67, 17-22. [CrossRef]

37. Osek, J. Rapid and specific identification of Shiga toxin producing Escherichia coli in feaces by multiplex PCR. Lett. Appl. Microbiol. 2002, 34, 304-310. [CrossRef]

38. Alfonzo, A.; Miceli, C.; Nasca, A.; Franciosi, E.; Ventimiglia, G.; Di Gerlando, R.; Tuohy, K.; Francesca, N.; Moschetti, G.; Settanni, L. Monitoring of wheat lactic acid bacteria from the field until the first step of dough fermentation. Food Microbiol. 2017, 62, 256-269. [CrossRef]

39. Gaglio, R.; Cirlincione, F.; Di Miceli, G.; Franciosi, E.; Di Gerlando, R.; Francesca, N.; Settanni, L.; Moschetti, G. Microbial dynamics in durum wheat kernels during aging. Int. J. Food Microbiol. 2020, 324, 108631.

40. Settanni, L.; Barbaccia, P.; Bonanno, A.; Ponte, M.; Di Gerlando, R.; Franciosi, E.; Di Grigoli, A.; Gaglio, R. Evolution of indigenous starter microorganisms and physicochemical parameters in spontaneously fermented beef, horse, wild boar and pork salamis produced under controlled conditions. Food Microbiol. 2020, 87, 103385. [CrossRef]

41. Logares, R.; Audic, S.; Bass, D.; Bittner, L.; Boutte, C.; Christen, R.; Claverie, J.M.; Decelle, J.; Dolan, J.R.; Dunthorn, M.; et al. Patterns of rare and abundant marine microbial eukaryotes. Curr. Biol. 2014, 24, 813-821.

42. Bockelmann, W.; Willems, K.P.; Neve, H.; Heller, K.H. Cultures for the ripening of smear cheeses. Int. Dairy J. 2005, 15, 719-732. [CrossRef]

43. Loong, S.K.; Lee, H.Y.; Khoo, J.J.; Lim, F.S.; Ahmad-Nasrah, S.N.; Azman, A.S.; Suntharalingam, C.; Panchadcharam, C.; AbuBakar, S. Microbiological analysis of raw milk unveiled the presence of a dairy contaminant, Corynebacterium lipophiloflavum. J. Appl. Biol. Biotechnol. 2019, 7, 41-44.

44. Di Gioia, D.; Aloisio, I.; Mazzola, G.; Biavati, B. Bifidobacteria: Their impact on gut microbiota composition and their applications as probiotics in infants. Appl. Microbiol. Biotechnol. 2014, 98, 563-577. [CrossRef]

45. Dinakar, P.; Mistry, V.V. Growth and viability of Bifidobacterium bifidum in Cheddar cheese. Int. J. Dairy Sci. 1994, 77, 2854-2864. [CrossRef]

46. Di Grigoli, A.; Francesca, N.; Gaglio, R.; Guarrasi, V.; Moschetti, M.; Scatassa, M.L.; Settanni, L.; Bonanno, A. The influence of the wooden equipment employed for cheese manufacture on the characteristics of a traditional stretched cheese during ripening. Food Microbiol. 2015, 46, 81-91. [CrossRef]

47. Carpino, S.; Randazzo, C.L.; Pino, A.; Russo, N.; Rapisarda, T.; Belvedere, G.; Caggia, C. Influence of PDO Ragusano cheese biofilm microbiota on flavour compounds formation. Food Microbiol. 2017, 61, 126-135. [CrossRef]

48. Scatassa, M.L.; Cardamone, C.; Miraglia, V.; Lazzara, F.; Fiorenza, G.; Macaluso, G.; Arcuri, L.; Settanni, L. Characterisation of the microflora contaminating wooden vats used for traditional Sicilian cheese production. Ital. J. Food Saf. 2015, 4509, 36-39. [CrossRef]

49. Bellassi, P.; Rocchetti, G.; Nocetti, M.; Lucini, L.; Masoero, F.; Morelli, L. A combined metabolomic and metagenomic approach to discriminate raw milk for the production of hard cheese. Foods 2021, 10, 109. [CrossRef] [PubMed]

50. Franciosi, E.; Settanni, L.; Cologna, N.; Cavazza, A.; Poznanski, E. Microbial analysis of raw cows' milk used for cheese-making: Influence of storage treatments on microbial composition and other technological traits. World J. Microbiol. Biotechnol. 2011, 27, 171-180. [CrossRef]

51. Lafarge, V.; Ogier, J.C.; Girard, V.; Maladen, V.; Leveau, J.Y.; Gruss, A.; Delacroix-Buchet, A. Raw cow milk bacterial population shifts attributable to refrigeration. Appl. Environ. Microbiol. 2004, 70, 5644-5650. [CrossRef]

52. Centeno, J.A.; Garabal, J.I.; Docampo, F.; Lorenzo, J.M.; Carballo, J. Recovering traditional raw-milk Tetilla cheese flavour and sensory attributes by using Kocuria varians and Yarrowia lipolytica adjunct cultures. Int. J. Food Microbiol. 2017, $251,33-40$. [CrossRef]

53. Hugo, C.J.; Segers, P.; Hoste, B.; Vancanneyt, M.; Kersters, K. Chryseobacterium joostei sp. nov., isolated from the dairy environment. Int. J. Syst. Evol. Microbiol. 2003, 53, 771-777. [CrossRef] 
54. Hantsis-Zacharov, E.; Halpern, M. Chryseobacterium haifense sp. nov., a psychrotolerant bacterium isolated from raw milk. Int. J. Syst. Evol. Microbiol. 2007, 57, 2344-2348. [CrossRef] [PubMed]

55. Hantsis-Zacharov, E.; Shaked, T.; Senderovich, Y.; Halpern, M. Chryseobacterium oranimense sp. nov., a psychrotolerant, proteolytic and lipolytic bacterium isolated from raw cow's milk. Int. J. Syst. Evol. Microbiol. 2008, 58, 2635-2639. [CrossRef]

56. Hantsis-Zacharov, E.; Halpern, M. Culturable psychrotrophic bacterial communities in raw milk and their proteolytic and lipolytic traits. Appl. Environ. Microbiol. 2007, 73, 7162-7168. [CrossRef]

57. Ishida, T.; Yokota, A.; Umezawa, Y.; Toda, T.; Yamada, K. Identification and characterization of lactococcal and Acetobacter strains isolated from traditional Caucasusian fermented milk. J. Nutr. Sci. Vitaminol. 2005, 51, 187-193. [CrossRef]

58. Kiryu, T.; Yamauchi, K.; Masuyama, A.; Ooe, K.; Kimura, T.; Kiso, T.; Nakano, H.; Murakami, H. Optimization of lactobionic acid production by Acetobacter orientalis isolated from Caucasian fermented milk, "Caspian Sea yogurt". Biosci. Biotechnol. Biochem. 2012, 1112272769 .

59. Sjöblom, S.; Brader, G.; Koch, G.; Palva, E.T. Cooperation of two distinct ExpR regulators controls quorum sensing specificity and virulence in the plant pathogen Erwinia carotovora. Mol. Microbiol. 2006, 60, 1474-1489. [CrossRef]

60. Cruciata, M.; Gaglio, R.; Todaro, M.; Settanni, L. Ecology of Vastedda della valle del Belìce cheeses: A review and recent findings to stabilize the traditional production. Food Rev. Int. 2019, 35, 90-103. [CrossRef]

61. Guarcello, R.; Carpino, S.; Gaglio, R.; Pino, A.; Rapisarda, T.; Caggia, C.; Marino, G.; Randazzo, C.L.; Settanni, L.; Todaro, M. A large factory-scale application of selected autochthonous lactic acid bacteria for PDO Pecorino Siciliano cheese production. Food Microbiol. 2016, 59, 66-75. [CrossRef]

62. Caldera, L.; Franzetti, L.V.; Van Coillie, E.; De Vos, P.; Stragier, P.; De Block, J.; Heyndrickx, M. Identification, enzymatic spoilage characterization and proteolytic activity quantification of Pseudomonas spp. isolated from different foods. Food Microbiol. 2016, 54, 142-153. [CrossRef]

63. Commission Regulation (EC) No 2073/2005 of 15 November 2005 on microbiological criteria for foodstuffs. Off. J. Eur. Union 2005, 338, 1-26. Available online: https:/ / eur-lex.europa.eu/legal-content/EN/ALL/?uri=CELEX\%3A32005R2073 (accessed on 30 June 2021).

64. European Food Safety Authority. European Centre for Disease Prevention and Control. The European Union One Health 2019 Zoonoses Report. EFSA J. 2021, 19, 6406.

65. Zheng, J.; Wittouck, S.; Salvetti, E.; Franz, C.M.; Harris, H.M.; Mattarelli, P.; O’Toole, P.W.; Pot, B.; Vandamme, P.; Walter, J.; et al. A taxonomic note on the genus Lactobacillus: Description of 23 novel genera, emended description of the genus Lactobacillus Beijerinck 1901, and union of Lactobacillaceae and Leuconostocaceae. Int. J. Syst. Evol. Microbiol. 2020, 7, 2782-2858. [CrossRef] [PubMed]

66. Randazzo, C.L.; Liotta, L.; Angelis, M.D.; Celano, G.; Russo, N.; Hoorde, K.V.; Chiofalo, V.; Pino, A.; Caggia, C. Adjunct Culture of Non-Starter Lactic Acid Bacteria for the Production of Provola Dei Nebrodi PDO Cheese: In Vitro Screening and Pilot-Scale Cheese-Making. Microorganisms 2021, 9, 179. [CrossRef] [PubMed]

67. Cronin, T.; Ziino, M.; Condurso, C.; McSweeney, P.L.H.; Mills, S.; Ross, R.P.; Stanton, C. A survey of the microbial and chemical composition of seven semi-ripened Provola dei Nebrodi Sicilian cheeses. J. Appl. Microbiol. 2007, 103, 1128-1139. [CrossRef] [PubMed] 